\title{
Ato Quayson, ed., The Cambridge Companion to the Postcolonial Novel
}

\section{Kerry-Jane Wallart}

\section{(2) OpenEdition \\ 1 Journals}

Electronic version

URL: https://journals.openedition.org/ces/4821

DOI: $10.4000 /$ ces. 4821

ISSN: 2534-6695

\section{Publisher}

SEPC (Société d'études des pays du Commonwealth)

\section{Printed version}

Date of publication: 1 September 2016

Number of pages: 133-134

ISSN: 2270-0633

\section{Electronic reference}

Kerry-Jane Wallart, "Ato Quayson, ed., The Cambridge Companion to the Postcolonial Novel",

Commonwealth Essays and Studies [Online], 39.1 | 2016, Online since 05 April 2021, connection on 18 June 2021. URL: http://journals.openedition.org/ces/4821 ; DOI: https://doi.org/10.4000/ces.4821

This text was automatically generated on 18 June 2021.

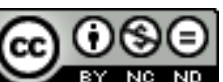

Commonwealth Essays and Studies is licensed under a Licence Creative Commons Attribution - Pas d'Utilisation Commerciale - Pas de Modification 4.0 International. 


\title{
Ato Quayson, ed., The Cambridge Companion to the Postcolonial Novel
}

\author{
Kerry-Jane Wallart
}

\section{REFERENCES}

Ato Quayson, ed. The Cambridge Companion to the Postcolonial Novel. Cambridge:

Cambridge University Press, 2016. 273 p. ISBN (pb): 9781107588059. £18.99

1 This precious critical overview of the main directions taken on by the postcolonial novel builds on familiar if highly topical analyses, which it summarizes and augments; it also presents itself as a turning point, leaving behind "the emphasis [...] to combine the explication of historical and political contexts with explorations of the rhetorical dimensions of the novels in question" (3). Ato Quayson's introduction contrasts what he calls, after Biodun Jeyifo, a heretofore prevailing "proleptic designation" with an "insterstitial or liminal postcoloniality" presented as more appropriate in the face of recent evolutions both in literary writing and critical theory. While acknowledging that such a distinction can be limited by some major authors (including Rushdie) actually straddling the fence, the editor argues that after 1989 and the invention of the world wide web, a hybrid cosmopolitan vein has turned its back to any nationalistic "will-toidentity." The perspective is thus shunning any ideological positioning, although political issues surface in Quayson's volume more than one could have deduced from the initial manifesto. This study renders the reprisal dimension of much of the postcolonial production while nuancing its strength or centrality through an emphasis on diasporic and transnational fiction. Also carefully scrutinized is a process of historical transition from one to the other.

Greatly contributing to the unity of the volume, the method is similar from one chapter to the next: all authors confront theory and fiction in a rather efficient dialogue where the latter is not stifling under the weight and impact of the former. Another strength of the book is its comparative take as novels written in French, Arabic, Hindi or African 
languages feature alongside those written in English, sometimes prominently so. Each chapter throws the reader into a whirlwind of unexpected connections between geographical spaces and literary worlds in a way fully aligned with Quayson's statement (in the introductory first chapter) in favour of hybrid cosmopolitanism. The reservations that could be formulated about such choices are the ones prevalent elsewhere: what about novels not written in European languages, not geared towards the Western readership so fond of Rushdie, Coetzee, Malouf, Okri and Kincaid? What of the Dalit, the Maori, the Kikuyu narratives, written and read within narrower geographical and cultural areas?

Chapter 2, authored by Tim Watson, grapples with the colonial novel and the concept of creolization it reflects; its apparently anomalous inclusion in the volume is convincingly explained by Watson. In the next chapter, Debjani Ganguly looks at how 1989 has initiated a turn from the concept of "world literature" into a "new world novel" staging "hyperconnected humans sensitized as witnesses to the depredations of gruesome global violence and the excesses of [...] capitalism" (44). In "Magical/Realist Novels and the Politics of the Possible," Zoe Norridge offers a renewed take on a current which could seem to be on the wane; rather than returning to German expressionism she connects it to French nineteenth-century naturalism/realism and browses through those postcolonial novelists deploying "literary realism's engagement with the world" (69); if her case studies are insightful, it is not always clear how she connects realism and magic realism and this ought to have been further conceptualised. While in the fifth chapter Anthony Carrigan helpfully recapitulates and develops the issues addressed by ecocriticism, the sixth one, "Disability and the Postcolonial Novel" (by Clare Barker) is probably the most up-to-date and connects postcolonial studies with the recently established field of "Disability Studies." A seventh chapter, by Evan Mwangi, confronts issues of gender and sexuality. Far from ignoring the fact that they are often silenced in postcolonial novels, Mwangi mostly focuses on African texts, where hyper-masculinity is dominant; he turns to those novels which resist through their staging of male prostitution or homosexuality.

Yoon Sun Lee takes stock of diasporic phenomena while Philip Dickinson traces the "itineraries of the sublime." The following text, by Stephen Knight, is concerned with the conventions of the crime novel; although it offers an impressively knowledgeable description of a wealth of primary sources, it fails to pin down the reasons for such prolixity (a will to wield justice, or to denounce the impossibility of the task, perhaps?). Chapter 11, by Rashmi Varma, focuses on representations of the city; although it could have been placed after the following chapter (on space) and partly fails to distinguish what is specifically novelistic about the representations it gleans, it is convincing in showing how the city, which had been "the perfect example of simultaneous exclusion and forced inclusion into the colonial project" (190), has been taken to play with such imperial legacies, decentering them. The twelfth chapter (by Robert Zacharias), on questions of space, is particularly interesting and adapts the spatial turn in its original way, comparing approaches to space in Jane Austen and V. S. Naipaul for instance. One last chapter, authored by Quayson himself, grapples with borrowings from tragic patterns ("Tragedy and the Postcolonial Novel") and renews the commonplace associating postcolonial adaptations with "writing back."

5 The volume includes a useful chronology spanning 1854 to 2014, although its layout on the page, with a very narrow column on the right-hand side dedicated to the 
publication of some major novels, makes its use sometimes awkward, leaving blanks everywhere on the rest of the pages for lack of corresponding historical events. The index is quite long and extremely well drawn. The bibliography is extensive and, by dint of the polyphonic quality of the volume, impressively comprehensive.

Although necessarily not encyclopaedic in scope, the volume is thorough, offering a precious overview of the various issues surrounding the postcolonial novel nowadays. If Africa does not feature more than India for instance, despite the editor's field of knowledge, one might wonder why the volume does not engage more with Canadian literature. It is all the more surprising since Zacharias, who embraces questions of space in Austen, Naipaul, Coetzee and Achebe, carefully avoids his own field of Canlit; the chapter on ecocriticism is the only one to include reflections on a Canadian author (Atwood). Additionally, one could deplore a somehow Eurocentric insistence on a certain amount of categories (the sublime, realism) and genres (tragedy, the crime novel), while the problematic assumption of the "novel" itself is insufficiently recontextualized in historical and geographical terms. Nonetheless, this remarkable volume fills a gap and appears as a welcome overview; it will certainly prove useful to students and teachers alike.

\section{AUTHORS}

\section{KERRY-JANE WALLART}

Kerry-Jane WALLART is a senior lecturer at Paris-Sorbonne. Her field is Caribbean Studies; she has authored articles on Derek Walcott, V. S. Naipaul, E. K. Brathwaite, Fred D'Aguiar, Caryl Phillips, Wilson Harris, Pauline Melville, Claude McKay, among other writers. Her focus is the migration and dissemination of generic constraints and conventions. She is currently at work on a monograph on the proliferation of dramatic or performative moments in various narrative genres, in twentieth-century Caribbean literature. 